\title{
DEVELOPING STUDENTS' READING SKILL THROUGH MAKING MULTIMODAL INFERENCES
}

\author{
Vina Nurviyani \\ Department of English Education, Faculty of Language and Literature, \\ Universitas Pendidikan Indonesia, Indonesia \\ Email: vinanurviyani19@gmail.com \\ Didi Suherdi \\ Department of English Education, Faculty of Language and Literature, \\ Universitas Pendidikan Indonesia, Indonesia \\ Email: suherdi_d@upi.edu
}

Iwa Lukmana

Department of English Education Department, Faculty of Language and Literature, Universitas Pendidikan Indonesia, Indonesia

Email: iwa.di.bandung@gmail.com

\begin{abstract}
APA Citation: Nurviyani, V., Suherdi, D., \& Lukmana, I. (2020). Developing students' reading skill through making multimodal inferences. English Review: Journal of English Education, 8(2), 175182. doi: 10.25134/erjee.v8i2.2998.
\end{abstract}

\begin{abstract}
This present study investigated the development of students' reading skills through making multimodal inferences. Moreover, the students' difficulties in making multimodal inferences were explored. This study applied a classroom action research by involving twenty students studying at English education program in West Java. Three instruments covering reading tests of making multimodal inference, classroom observations, and questionnaire were conducted as data collections of this study. The results of this study indicate that the students' reading skills improved significantly after making multimodal inferences. In the first cycle, sixty three percent of all students achieved the score more than seventy. Meanwhile, in the second cycle, eighty five percent of all students reached the score more than eighty-seven. It is reflected on the data gained from reading tests, classroom observations, and questionnaire. The findings show that almost all students achieved meaningful progress of reading skills through making multimodal inferences that they were able to make inferences visually and verbally by using the clues of the texts and integrating it with their background knowledge, creating mental images in their minds, distinguishing between literal and implied meanings, implementing some reading strategies before, during, and after reading the text, and manifesting their inferences visually and verbally on Canva application. Thus, they were able to master micro and macro skills of reading comprehension and comprehend the multimodal texts completely. However, in making multimodal inference, some students got troubles in integrating visual and verbal aspects because of incomplete background knowledge in their minds. Therefore, the manifestation of their multimodal inferences was presented partially.
\end{abstract}

Keywords: reading skills; multimodal inferences; canva.

\section{INTRODUCTION}

Reading is one of important skill in foreign language learning ( $\mathrm{Yu}, 2015)$. It is generally defined as the process of recognition and comprehension of written materials (Heriyawati, Saukah, \& Widiati, 2018). In similar vein, Kasımi (2012), Pearson and Cervetti (2013), and Alyousef (2005) argue that reading is a complex process integrating some cognitive processes, skills, text knowledge, strategic knowledge, and contexts to construct meaning from a reading material and interpret the information. In the similar vein, it is stated that the primary purpose of reading is to interpret or comprehend a text
(Namaziandost, Fadhly, \& Solihat, 2019) and comprehension is the core of reading (Kitson, 2011).

In digital era, comprehension of English texts is inevitably. However, it is challenging activities for several EFL students. The comprehension of reading is influenced by text, task, reader, and contextual variables (Afflerbach, Pearson, \& Paris, 2008; Kitson, 2011). Incomplete vocabulary knowledge (Nurjanah, 2018; Qarqez \& Rashid, 2017), and inability to recognize text types (Al-Jarrah \& Ismail, 2018), low reading interest, less culture background knowledge ( $\mathrm{Yu}$, 2015), have become parts of reading difficulties 
in EFL contexts. The reading difficulties are getting complex as reading materials are presented as an integration of various modes. It is a combination of written text with images, colour, space, sound, movements and gestures. The images cover photos, pictures, emoticons, and graphics; and cyber links connecting texts in a single display (Suherdi, 2015). It is called as multimodal texts (Walsh, 2015).

Reading materials can be monomodal or multimodal texts. The reading material conducted by students as readers can be personal or academic reading. The personal reading covers newspapers, magazines, letters, emails, greeting cards, invitations, messages, notes, lists, blogs, schedule (e.g. train, bus, plane, etc), recipes, menus, maps, calendars, advertisement (commercials, want, adv), novels, short stories, jokes, dramas, poetry, financial documents (e.g. checks, tax forms, loan application), forms, questionnaires, medical reports, immigration documents, comic strips, and cartoons (Brown \& Abewickrama, 2010). Meanwhile, academic reading covers general interest articles such as magazine, newspaper; technical reports such as lab reports, professional journal articles; reference material such as dictionary, online encyclopaedias' textbook; thesis; essay; papers; test directions; editorial and opinion writing. Either personal or academic reading material is presented in various types, forms, graphic features, topics, styles, intended readerships, lengths, readabilities or difficulties, range of vocabulary and grammatical structures (Hughes, 2003).

The reading difficulties effect low reading comprehension skills. In the meantime, multimodal texts become more popular in education particularly in reading materials (Cahyaningati \& Lestari, 2018) and advanced reading skills are essential for success of students (Marschall \& Davis, 2012). In this case, A reading skill is a cognitive ability which a person is able to use when interacting with the written texts (Bojovic, 2010).

In digital era, students as reader should master the micro kills and macro skills of reading comprehension to comprehend multimodal texts totally. The reading skills cover micro skills and macros kills of reading comprehension (Brown \& Abewickrama, 2010). The micro skills of reading comprehension consist of: 1) discriminate among the distinctive grapheme (letter or letter combination the produce a phoneme) and orthographic patterns of English; 2) retain chunks of language of different lengths in short term memory; 3) process writing at an efficient rate of speed to suit the purpose; 4) recognize a core of words and interpret word order patterns and their significance; 5) recognize grammatical word classes (nouns, verbs, etc), system (e.g. tense, agreement, pluralization), patterns, rules, and elliptical forms; 6) recognize that a particular meaning may be expressed in different grammatical forms; and 7) recognize cohesive devices in written discourse and their role in signalling the relationship between and among clauses (Brown \& Abewickrama, 2010; Gail, 2017).

Meanwhile, the macro skills of reading comprehension cover: 1) recognize the rhetorical conventions of written discourse and their significance for interpretation; 2) recognize the communicative functions of written texts, according to form and purpose; 3 ) infer context that is not explicit by activating schemata (using background knowledge); 4) from described events, ideas, etc, infer links and connections between events, deduce causes and effects, and detect such relations as main idea, supporting idea, new information, given information, generalization. And exemplification; 5) distinguish between literal and implied meanings; 6) detect culturally specific inferences and interpret them in a context of the appropriate cultural schemata; and 7) develop and use a battery of reading strategies, such as scanning and skimming, detecting discourse markers, guessing the meaning of words from context, and activating schemata for the interpretation of texts (Brown \& Abewickrama, 2010).

Their reading comprehension skills can be developed by implementing some reading strategies (Kucukoglu, 2013). One of the reading strategies is making inference (Harvey \& Goudvis, 2017; Block \& Israel, 2005). Making inference means readers guess the writer's massage of the text by referring some clues presented in the texts with their own experiences (Harvey \& Goudvis, 2007; Serafini, 2004).

Kispal (2008) proposes some types of inferences, such as 1) coherence inferences; 2) elaborative inferences, it is also known as gapfilling inferences; 3) Local inferences; 4) Global inferences; 5) On-line inferences; and 6) Off-line inferences. Each types of inference is elaborated below.

Concerning coherence inference, is known as text-connecting or inter sentence inferences. It is a type of inferences that readers maintain textual 
integrity. For example, in the sentence Peter begged his mother to let him go to the party. In process of conducting the type of inference, the reader has to realize that the pronouns 'his' and 'him' refer to Peter to fully understand the meaning.

Regarding elaborative inferences, it is also known as gap-filling inferences. In conducting this kind of inference, readers enrich the mental representation of the text, e.g: Katy dropped the vase. She ran for the dustpan and brush to sweep up the pieces. Moreover, the reader would have to draw upon life experience and general knowledge to realize that the vase broke to supply the connection between these sentences.

Discussing local inferences, in this session readers create a coherent representation at the local level of sentences and paragraphs.

Regarding global inferences, in implementing this inference, readers make a coherent representation covering the whole text. In this case, the reader needs to infer overarching ideas about the theme, main point or moral of a text by drawing on local pieces of information.

Concerning on-line inferences, readers draw inferences automatically during reading. In offline inferences, readers drawn inferences strategically after reading.

Regarding reading skills, works on the issues have been developed for many years. Some authors have explored the impacts of some aspects to develop students' reading skills. Sporer, Brunstein, \& Kieschke (2009) explored the effects of strategy instruction and reciprocal teaching to improve students' reading skills. Moreover, Kucukoglu (2013) examined the improvement of student comprehension skills through instruction of reading strategies. Besides, Yang (2014) explored the effective methods to improving reading skills in English study. Similarly, Nhapulo, Simon, \& Herreweghe (2017) investigated Southern African linguistics and applied language studies enhancing academic reading skills through extensive reading. Besides, Ismail, Syahruzah, \& Basuki (2017) examined the improvement of the students' reading skill through translation method.

Furthermore, it is becoming increasingly influential as one of aspects should be mastered by students as readers to comprehend multimodal texts completely. Cote \& Milliner (2014) investigated L2 micro-skills to English reading comprehension for adult community college ELL students. In the similar vein, Boshrabadi \& Biria (2014) explored the efficacy of multimodal vs. print-based texts for teaching reading comprehension skills to Iranian high school third graders. Moreover, Cahyaningati \& Lestari (2018) explored the use of multimodal text in enhancing reading skills.

With respect to making inference, some studies exploring the inferences have been carried out, such as the research of implementation of multimodal inferences in vehicle-driver interaction (Sezgin, Davies, \& Robinson, 2009); effects of making reading inference on selfesteem (Wilson, Kim, Raudenbush, \& Kim, 2017), implementation of inference strategy (Jumiaty, 2014; Attaprechakul, 2013; Rieskamp, 2008); and effectiveness of teaching making inferences in reading (Kispal, 2008).

Referring to the studies, the study investigating the development of students' reading skills through reading strategies, especially multimodal inference strategy is still rare. In this case, making multimodal inference means the readers predict writer's intention of text by referring to some text clues, before, during and after reading process by integrating some modes such as visual, verbal, spatial, and gesture, presented digitally or non-digitally.

In line with the background above, this research attempts to address the following questions: 1) How is the effectiveness of making multimodal inferences in developing students' reading skills? and 2) What are students' difficulties of making multimodal inferences in developing students' reading skills?

\section{METHOD}

This study implemented classroom action research consisting two cycles and conducted in a class of reading. The classroom action research was implemented to improve students' reading skills in making multimodal inferences and to explore students' difficulties in making multimodal inferences. Each cycle covered four stages namely a) plan, b) act, c) observe, and d) reflect as proposed by Costello (2007). Each stage is explained in detail below.

The first stage, plan, is finding a problem of reading by carrying out a preliminary investigation of students' reading skills, then forming a hypothesis and taking a number of strategies for conducting the next stage, actions. The second stage, act, is conducting teachinglearning processes to improve students' achievement of reading skills. In this stage, the students got some guidance to foster their reading skills by making multimodal inference. The third 
stage is observing the teaching -learning processes of implementing multimodal inferences to improve students' reading skills, whether the instruments run well or need some revisions. The last stage is reviewing, evaluating and comparing the results concerning the improvement of students' reading skills by making multimodal inferences, and planning the next cycle. When the findings of the first cycle show insignificant results, the next cycle had to carry out (see Costello, 2003; Nunan, 2002).

In conducting classroom action research, some data collections techniques covering reading tests of making multimodal inferences, classroom observations, and questionnaire were applied. All instruments were implemented to investigate the development of students' reading comprehension skills through making multimodal inferences and to find out their difficulties in composing the multimodal inferences. In collecting each data, the participants were twenty students studying at English department program of a private university in West Java, Indonesia. Thus, in this study each student played three roles.

Concerning reading tests, Brown \& Abewickrama (2010) explain that one of interactive reading assessments is information transfer conducted by reading charts, maps, graphs, diagrams. The graphic features include: tables, charts, diagrams, cartoons, illustrations (Hughes, 2003). In this case, information transfer is an act of comprehending graphs from reading verbal and or non-verbal information.

Furthermore, Brown \& Abewickrama (2010) recommend some tasks for assessing the interpretation of graphic information, namely: a) reading a graphic by answering simple, direct information questions; b) reading a graphic by describing or elaborating information; c) reading a graphic by inferring or predicting information; d) reading a passage by choosing the correct graphic for it; e) reading a passage with an accompanying graphic by interpreting both; f) reading a passage by creating or using a graphic to illustrate.

In line to the description, Nation (2009) categories the task types of post-reading comprehension into four levels, namely: a) literal comprehension, in this level students have to answer some questions after reading section to measure their understanding concerning what the text explicitly says; b) drawing inference, this type of task is conducted to examine students' reading comprehension skills in implementing reading between the line, using text information that is not explicitly stated but which can be justified by reference to the text; c) using the text for other purpose, this level of task is implemented to explore students' reading comprehension skills in applying information in the text to some problems, reflecting on personal experiences, comparing with ideas from other sources, and extending information beyond the text; d) responding critically, in conducting this type of task, students' reading comprehension skills are examined by evaluating adequacy of content, quality of evidence, author bias, quality of expression, agreement or disagreement with ideas in the text, and satisfaction or dissatisfaction with the text.

Referring to the theory, the reading tests of this study were reading a graphic text by inferring or predicting information of texts (see Brown \& Abewickrama, 2010). The tests were conducted as post-reading comprehension tasks (see Nation, 2009). In this case, the students read between the line of Report texts presented as a multimodal text. Then they used the text information that was not explicitly stated but which could be justified by reference to the text. Finally, the manifestation of their multimodal inferences was presented visually and verbally in Canva application.

Concerning a Report text, it is one of text types containing a fact of a subject, a description and information on its parts, behavior, and qualities (Anderson \& Anderson, 2003b, 2003b; Feez and Joyce, 1998; cited in Nurviyani, 2012).

Meanwhile, Canva is a tool making possible designs of anything and publish anywhere. It is operated in smartphone and desktop. Over 400 million designs from more than 10 million users across 179 countries have been created with Canva. Moreover, Canva is available in 100 languages and can be accessed in desktop browsers and mobile apps. It makes Canva accessible to everyone with internet connection. In addition, by implementing Canva, a creative beautiful designs and documents are created for any occasions and purposes (Canva, 2019). In this study, Canva is one of digital applications applied as a digital instructional media in making multimodal inferences.

In this research, the reading tests were conducted twice and presented on Canva application by using similar material, concerning Report text but in different theme for the first and the second cycle. The reading tests were posed to students at the end of the third stage of each 
cycle. The tests of making multimodal inferences were held for ninety minutes for each test.

Concerning observations, it was conducted for five meetings, namely three meetings for the first cycle and two meetings for the second one. In these sessions, the researcher positioned herself as the lecturer who immediately saw and heard what was happening as recommended by Nunan (2002). It means that in this study the researcher observed what was going on during the teaching-learning process of making multimodal inferences by applying the Canva application to develop students' reading comprehension skills. Moreover, the researcher also interacted with participants during the teaching-learning process of making multimodal inferences.

Regarding questionnaire, this study employed open-ended questionnaires. The students got the questionnaire at the end of the second cycle. In this session, the students as the research participants had to fill the blank space to answer ten questions in detail because there are no options in each question. The questions of the questionnaire explored the students' reading comprehension skills through making multimodal inferences and the students' difficulties in making multimodal inference (see Dornyei, 2007). In this case, the data gained from the questionnaire were applied to explore the verbal and non verbal information presented in graphic features, concerning reading skills developed through making multimodal inference, and students' difficulties in composing the inferences. The questionnaires were presented in Indonesian to make the students free in expressing their ideas and comprehend the questions more easily.

Furthermore, the data gained from the questionnaire, reading tests, and classroom observations, were analysed qualitatively, categorized, and then interpreted into two categories based on the research questions.

\section{RESULTS AND DISCUSSION}

This study applying classroom action research investigated the development of students' reading skill through making multimodal inferences. Moreover, the students' difficulties in making multimodal inferences were examined. The data collection techniques implemented for both research purposes were reading tests, questionnaire, and classroom observations conducted in two cycles.

In the first cycle, the classroom action research was begun by conducting the first stage of classroom action research, it is plan. The plans covered the stating the problem and conducting preliminary investigation of students' reading skills. The problem was many college students have trouble in comprehending multimodal texts particularly in making inferences, either personal reading or academic reading. Moreover, the lesson plans were designed for the first cycle, then all documents and some devices needed for teaching making multimodal inferences such as smart phones and Canva application were prepared. Next, the students were recognized to Canva application as the digital tool for making multimodal inference. Then they installed the Canva application in their smartphones or laptop and learnt how to operate the application for presenting something. Afterword, they practiced making something on Canva application in pairs.

Next stage, action and observation. In these stages, the students learnt making multimodal inferences through three steps namely prereading, while reading and post-reading (see Marschall \& Davis, 2012). In the step of prereading or before reading, the students identified the purpose and type of reading. This study focused on Report texts presented in an online newspaper.

In while reading session, the students explored the social function, the grammatical structure, and linguistics features of Report texts. Besides, the students explored topic sentences and supporting sentences related to the topics of the texts. Next, the students as the readers learnt making inferences as one of reading strategies and the types of making inferences as recommended by Kispal (2008) as well, such as 1) coherence inferences; 2) elaborative inferences, it is also known as gap-filling inferences; 3) Local inferences; 4) Global inferences; 5) On-line inferences; and 6) Off-line inferences. Before learning making inferences at the session, the students had learnt other reading strategies such as making connection, visualizing, summarising, and synthesizing in the previous meetings (see Harvey \& Goudvis, 2007). Then, the students got some models of making multimodal inferences. Next, the students made continuous prediction about the content of the Report texts and what would happen next in the texts.

In post-reading session, the students practiced making multimodal inferences verbally and visually by creating some pictures on their minds. It was as the results of integration between the students' background knowledges with some 
visual and verbal information as clues presented on the Report texts they had read. Their manifestations of the multimodal inferences were presented on Canva application. Next, the students and the lecturer shared and discussed it together.

The last, the students got reading test of making multimodal inferences individually. The test was conducted to evaluate and measure the students' reading comprehension skills through making multimodal inferences and students' difficulties in making multimodal inferences in the first cycle. In the test, the students had to make inferences verbally and visually based on the clues of a Report text derived from an online newspaper. Then their manifestations of multimodal inferences were presented on Canva application as the previous session.

The last stage was reflection. It was carried out to review, evaluate and compare the results and the plan of the first cycle. This stage was conducted after all data gained from reading test and classroom observations were collected completely. It was conducted to evaluate the students' reading comprehension skills through making multimodal inferences and the students' difficulties in making the multimodal inferences.

Referring to the data obtained from the reading test and the classroom observations of the first cycle, it was found that the learning outcome of making multimodal inferences for developing students' reading comprehension skills had not been achieved significantly. The results of the reading test show that only sixty three percent of all students achieved score of more than seventy. It means that some students were able to make verbal and visual inferences on Canva application and comprehend the Report texts completely. Meanwhile the other ones got confused in making multimodal inferences, such as some students got troubles in making visual and verbal inferences in their minds and on Canva application, and had difficulties to integrate the information of the texts with their background knowledge in making inferences. It can be seen from incomplete verbal inferences and irrelevant images inserted to verbal inferences on Canva application. Therefore, they comprehended the Report text partially.

Due to the students' reading skill through making multimodal inferences had not shown meaningful progress, the second cycle of the classroom action research was conducted. The second cycle of the classroom action research was implemented similarly as the first one. It consisted of four stages, namely plan, act, observe and reflect (see Costello, 2003; Nunan, 2002).

In the second cycle, the classroom action research was begun by implementing a plan as the first stage of classroom action research. In the stage, the problems based on the achievement of students' reading comprehension skills through making multimodal inferences in the first cycle were stated. Referring to the reflection stage of the first cycle, the results show insignificant. Thus, there should be some improvements and revisions to be applied in the second cycle.

The next stages were action and observation. In this stage, the teaching methodology was designed differently and remedial teachinglearning process of making multimodal inferences was conducted to improve students' reading comprehension skills. The material of this cycle was similar to the previous one. It was Report text derived from an online newspaper. Besides, the students got more practices integrating verbal and visual aspects of the texts and creating mental images in their minds in making multimodal inferences. Moreover, they got remedial reading test of making multimodal inferences presented on Canva application. Having getting the reading test, the students got questionnaire investigating their improvement of reading comprehension skills through making multimodal inferences and their difficulties in making the inferences.

Referring to the results of reflection as the last stage of the second cycle of the classroom action research, the findings gained from the reading test show that the students' reading comprehension skills improved meaningfully. It can be seen from the students' scores of reading test that eighty five percent of all students achieved the score more than eighty-seven. It showed the significant difference, compared with the first cycle.

Moreover, the results gained from classroom observations and questionnaire showed that the students were able to apply micro skills and macro skills of reading comprehension before, during and after reading Report text, such as inferring context that is not explicit visually and verbally by activating their background knowledge, distinguishing between literal and implied meanings, and implementing some reading strategies before, during, and after reading the text. Thus, they were able to comprehend the Report texts completely and make visual and verbal inferences in their minds 
and their manifestations were presented on Canva application totally. It means that almost all students achieved meaningful progress of reading skills through making multimodal inferences. Therefore, the difficulties encountered by students in making inferences through Canva application had been overcome totally.

\section{CONCLUSION}

By drawing on the data analysis, the findings show that making multimodal inferences is an effective stretegy to improve students' reading comprehension skills. Their reading skills develop significantly, either micro skills or macro skills of reading comprehension.

The development of students' micro reading comprehension skills are indicated as students as readers recognize grammatical word classes, word system, patterns, rules, and elliptical forms; recognize particular meaning expressed in different grammatical forms. It is relevant to the statement proposed by Brown and Abewickrama (2010) and Gail (2017).

Regarding students' macro reading comprehension skills, the findings show that they recognize the purpose of the text; infer explicit context by connecting with their background knowledge; describe events, and ideas; infer links and connecte between events; deduce causes and effects, and detect such relations as main idea, supporting idea, new information, given information, generalization and exemplification; distinguish between literal and implied meanings; detect culturally specific inferences and interpret them in a certain social cultural context. Moreover, they use some reading strategies, such as scanning and skimming, detecting discourse markers, guessing the meaning of words from context, and activating schemata for the interpretation of texts. It It is relevant to the statement proposed by Brown and Abewickrama (2010).

Referring to the statement, it can be assumed that making multimodal inferences is an assimilation and integration processes of some reading strategies such as the integration between readers' background knowledge with the information of the texts, visualization, summarizing, scanning, skimming, and making inference. In this case, visualization strengthens inferential thinking. It is relevant to the statement of Harvey \& Goudvis (2017).

By creating multimodal inferring, students are able to draw conclusions, make predictions, identify underlying themes, use information to create meaning from text, and use pictures to construct meaning. It is appropriate with the statement recommended by Harvey \& Goudvis (2017).

\section{REFERENCES}

Afflerbach, P., Pearson, D., \& Paris, S. G. (2008). Clarifying differences between reading skills and reading strategies. The Reading Teacher, 61(5), 364-373.

Al-Jarrah, H., \& Ismail, N. S. B. (2018). Reading comprehension difficulties among EFL learners in higher learning institutions. International Journal of English Linguistics, 8(7), 32. doi: 10.5539/ijel.v8n7p32.

Alyousef, H. S. (2005). Teaching reading comprehension to ESL /EFL learners. The Reading Matrix, 5(2), 379-380.

Anderson, M., \& Anderson, K. (2003a). Text types in English 1. South Yarra, Australia: Macmillan Education Australia.

Anderson, M., \& Anderson, K. (2003b). Text types in English 2. South Yarra, Australia: Macmillan Education Australia.

Attaprechakul, D. (2013). Inference strategies to improve reading comprehension of challenging texts. English Language Teaching, 6(3), 82-91. doi: 10.5539/elt.v6n3p82.

Block, C., \& Israel, S. (2005). Reading first and beyond: The complete guide for teachers and literacy coaches. Thousand Oaks: Corwin Press.

Bojovic, M. (2010). Reading skills and reading comprehension in English for specific purposes. The International Language Conference on the Importance of Learning Professional Foreign Language for Communication between Cultures.

Brown, H. D., \& Abewickrama, P. (2010). Language assessment: Principles and classroom practice (2nd ed.). New York: Pearson Education, Inc.

Cahyaningati, D. T., \& Lestari, L. A. (2018). The use of multimodal text in enhancing engineering students' reading skill. International Journal of Language Education, 2(2), $65 . \quad$ doi: 10.26858/ijole.v2i2.6360.

Costello, P. J. M. (2007). Continum research methods: Action research. London: Continum International Publishing Group.

Cote, T., \& Milliner, B. (2014). Extensive reading on mobile devices: Is it a worthwhile strategy? Proceedings of the 12th Asia TEFL and 23rd MELTA International Conference $28-30$ August 2014, (October 2015). doi: 10.13140/2.1.3812.2885.

Dornyei, Z. (2007). Research methods in applied linguistics, quantitative, qualitative and mix methodology. Oxford: Oxford University Press.

Harvey, S., \& Goudvis, A. (2007). Strategies that work: Teaching comprehension for understanding and engagement. Portland, ME: Stenhouse Publishers. 
Harvey, S., \& Goudvis, A. (2017). Strategies that work: Engagement, comprehension for understanding, engagement, and building knowledge ( $3^{\text {rd }}$ ed.). Portland, Maine: Stenhouse Publishers.

Heriyawati, D. F., Saukah, A., \& Widiati, U. (2018). Working memory capacity, content familiarity, and university EFL students' reading comprehension. Indonesian Journal of Applied Linguistics, $\quad 8(1), \quad 21-27 . \quad$ doi: 10.17509/ijal.v8i1.11458.

Hughes, A. (2003). Testing for language teachers. Cambridge: Cambridge University Press.

Ismail, H., Syahruzah, J. K., \& Basuki. (2017). Improving the students' reading skill through translation method. Journal of English Education, 2(2), 124-131.

Jumiaty, A. A. (2014). Inference strategy to improve the students' literal comprehension. Exposure Journal, 3(2).

Kasimi, Y. (2012). Cognitive and metacognitive strategies employed by Iranian and Turkish EFL readers. ELT Research Journal, 1(3), 159-174.

Kispal, A. (2008). Effective teaching of inference skill for reading. London.

Kitson, L. (2011). Reconceptualising understandings of texts, readers and contexts: One English teacher's response to using multimodal texts and interactive whiteboards. English in Australia, 46(3), 76-86.

Kucukoglu, H. (2013). Improving reading skills through effective reading strategies. Akdeniz Language Studies Conference, 70, 709-714. doi: 10.1016/j.sbspro.2013.01.113.

Marschall, S., \& Davis, C. (2012). A conceptual framework for teaching critical reading to adult college students, 23(2), 63-68. doi: $10.1177 / 1045159512444265$.

McIntyre, E., Hulan, N., \& Layne, V. (2011). Reading instruction for diverse classrooms. New York: The Guilford Press.

Namaziandost, E., Fadhly, F. Z., \& Solihat, D. (2019). Males and females discrepancies in reading fluency: Focusing on advanced EFL learners. English Literature and Language Review, 8(1), 11-18. doi: 10.25134/erjee.v8i1.1818.

Nation, I. S. P. (2009). Teaching ESL/EFL reading and writing. New York: Routledge.

Nhapulo, M. A., Simon, E., \& Herreweghe, M. Van. (2017). Southern African linguistics and applied language studies enhancing academic reading skills through extensive reading. Southern Africann Linguistics and Applied Language Studies, 3614(April). doi: 10.2989/16073614.2016.1267578.

Nunan, D. (2002). Research methods in language learning. Shanghai: Shanghai Foreign Language.

Nurjanah, R. L. (2018). The analysis on students' difficulties in doing reading comprehension final test. Metathesis: Journal of English Language, Literature, and Teaching, 2(2), 253. doi: 10.31002/metathesis.v2i2.958.

Pearson, P. D., \& Cervetti, G. (2013). The psychology and pedagogy of reading processes. In Handbook of Pscyhology, Volume 7: Educational Psychology. New York, United State: John Wiley and Sons.

Qarqez, M., \& Rashid, R. A. (2017). Reading comprehension difficulties among EFL learners: The case of first and second year students at Yarmouk University in Jordan. Arab World English Journal (AWEJ), 8(3), 421-431. doi: 10.1017/CBO9781107415324.004.

Rieskamp, J. (2008). The importance of learning when making inferences. Judgment and Decision Making, 3(3), 261-277.

Sezgin, T. M., Davies, I., \& Robinson, P. (2009). Multimodal inference for driver-vehicle interaction multimodal inference for drivervehicle interaction. ICMI-MLMI'09, 24(January). doi: 10.1145/1647314.1647348.

Sporer, N., Brunstein, J. C., \& Kieschke, U. (2009). Improving students' reading comprehension skills: Effects of strategy instruction and reciprocal teaching. Learning and Instruction, 19, 272-286. doi: 10.1016/j.learnin struc.2008.05.003.

Suherdi, D. (2015). Multimodal pedagogy in TEFLIN contexts. The 62nd TEFLIN International Conference 2015. Sanur, Bali: TEFLIN.

Wallace, C. (2003). Critical reading in language education. New York: Palgrave Macmillan.

Walsh, M. (2015). Reading visual and multimodal texts: How is "reading"different? Proceedings of the ALEA/UNE 2004 Conference," Multiliteracies and English K-12 in the Age of Information and Communication Technologies 2004, (May), 25-27.

Wilson, A., Kim, W., Raudenbush, B., \& Kim, M. (2017). The effects of making reading inferences on mastery goals, self-esteem and the effects of making reading inferences on mastery goals, self-esteem and TOEIC reading comprehension. North American Journal of Psychology, 19(1), 41-50.

Woolley, G. (2010). Developing reading comprehension: Combining visual and verbal cognitive processes. Australian Journal of Language \& Literacy, 33(2), 108-125.

Yang, Z. (2014). Effective methods to improving reading skills in english study. International Conference on Education, Language, Art and Intercultural Communication (ICELAIC), 284 286. Atlantis Press.

$\mathrm{Yu}$, J. (2015). Analysis of critical reading strategies and its effect on college English reading. Academy Publication, 5(1), 134-138. doi: 10.17507/tpls.0501.18. 